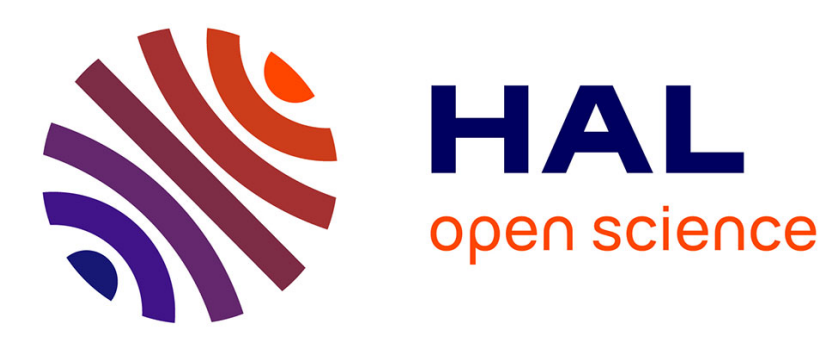

\title{
Identifying gastropod spawn from DNA barcodes: possible but not yet practicable
}

N. Puillandre, E. E Strong, P. Bouchet, M.-C. Boisselier, A. Couloux, S

Samadi

\section{- To cite this version:}

N. Puillandre, E. E Strong, P. Bouchet, M.-C. Boisselier, A. Couloux, et al.. Identifying gastropod spawn from DNA barcodes: possible but not yet practicable. Molecular Ecology Resources, 2009, 9 (5), pp.1311-1321. 10.1111/j.1755-0998.2009.02576.x . hal-02458063

\section{HAL Id: hal-02458063 https://hal.science/hal-02458063}

Submitted on 28 Jan 2020

HAL is a multi-disciplinary open access archive for the deposit and dissemination of scientific research documents, whether they are published or not. The documents may come from teaching and research institutions in France or abroad, or from public or private research centers.
L'archive ouverte pluridisciplinaire HAL, est destinée au dépôt et à la diffusion de documents scientifiques de niveau recherche, publiés ou non, émanant des établissements d'enseignement et de recherche français ou étrangers, des laboratoires publics ou privés. 
4 N. Puillandre ${ }^{*}, 1$, E.E. Strong ${ }^{2}$, P. Bouchet ${ }^{3}$, M.-C. Boisselier ${ }^{1}$, A. Couloux ${ }^{4}$ \& S. Samadi ${ }^{1}$ 5

$6 \quad{ }^{1}$ Université Pierre et Marie Curie (UPMC), UMR 7138, Systématique, adaptation, évolution 7 (UPMC/IRD/MNHN/CNRS), CP26, 57 rue Cuvier, 75231 Paris Cedex 05, France.

$8 \quad{ }^{2}$ Department of Invertebrate Zoology, Smithsonian Institution, National Museum of Natural 9 History, MRC 163, P.O. Box 37012, Washington, DC 20013-7012, USA.

${ }^{3}$ Muséum National d'Histoire Naturelle, 57 rue Cuvier, 75231 Paris Cedex 05, France.

${ }^{4}$ GENOSCOPE, Centre National de Séquençage, Evry, France.

Keywords: DNA barcoding, egg capsules, Neogastropoda, Barcode of Life Database, 14 GenBank

15

16

17

18

Running title: Barcoding gastropod spawn

* Corresponding author: UMR 7138, Systématique, adaptation, évolution, UPMC; IRD; MNHN; CNRS, Service de systématique moléculaire (CNRS, IFR 101), Département systématique et évolution, Muséum National d’Histoire Naturelle, CP26, 57 rue Cuvier, 75231 Paris Cedex 05, France.; puillandre@mnhn.fr; +33 140793743 


\section{Abstract}

Identifying life stages of species with complex life histories is problematic as species are often only known and/or described from a single stage. DNA barcoding has been touted as an important tool for linking life history stages of the same species. To test the current efficacy of DNA barcodes for identifying unknown mollusk life stages, 24 marine gastropod egg capsules were collected off the Philippines in deep-water and sequenced for partial fragments of the COI, 16S and 12S mitochondrial genes. Two egg capsules of known shallow-water Mediterranean species were used to calibrate the method. These sequences were compared to those available in GenBank and the Barcode of Life Database (BOLD). Using COI sequences alone, only a single Mediterranean egg capsule was identified to species, and a single Philippine egg capsule was identified tentatively to genus; all other COI sequences recovered matches between $76 \%$ and 90\% with sequences from BOLD and GenBank. Similarity-based identification using all three markers confirmed the Mediterranean specimens’ identifications. A phylogenetic approach was also implemented to confirm similarity-based identifications and provide a higher-taxonomic identification when species-level identifications were not possible. Comparison of available GenBank sequences to the diversity curve of a well sampled coral reef habitat in New Caledonia highlights the poor taxonomic coverage achieved at present in existing genetic databases, emphasizing the need to develop DNA barcoding projects for megadiverse and often taxonomically challenging groups such as mollusks, to fully realize its potential as an identification and discovery tool. 


\section{Introduction}

Identification of different life stages for species with complex life histories has long posed a challenge to biologists of almost every discipline as species are routinely known and/or described based only on a single stage. Identifying early life stages is particularly difficult for marine invertebrates including mollusks that often undergo dramatic metamorphoses from the egg to one or more larval stages before finally reaching juvenile and adult form. The issue is trivial in mollusk species with parental care, but these represent only a small minority, the vast majority dispersing their larvae or their spawn (e.g. Lebour 1937; Fretter \& Graham 1962; Robertson 1974) sometimes vast distances through ocean currents.

Mollusk spawn are highly conservative within species and present features that are diagnostic at many taxonomic levels, providing another character set useful for understanding evolutionary relationships (e.g. Habe 1960; Robertson 1974; Bandel 1976a,b). But due to the difficulties inherent in identification, spawn have been described for only several hundred species at best, with the tropical mollusk fauna particularly poorly known. This limits the utility of spawn in systematic and ecological studies.

The process of identifying mollusk spawn typically relies on serendipitous discoveries of individuals actively depositing eggs, painstaking and time-consuming breeding and rearing of larvae ex situ, or circumstantial evidence (species presence, abundance) and a process of elimination using criteria including substrate, spawn morphology, developmental mode, ovum size, ovary/ovum color, etc. (e.g. D’Asaro 1970; Winner 1987; Gustafson et al. 1991). However, in situ observations or ex situ rearing of juveniles are often impractical or may be impossible, e.g. in vent (Lutz et al. 1986) and other deep-water species (present study). 
71 Classic surveys of molluscan spawn have focused on northern temperate biomes with low

numbers of species and are almost exclusively limited to species with intra-capsular development (crawl-away juveniles) allowing comparisons between near-hatching embryos and the protoconchs of known adults. Such conditions provide an adequately simple system facilitating the identification of larvae and spawn (Thorson 1940b). But even after careful scrutiny of the protoconchs, this approach may still be fallible and lead to incorrect identifications in a certain number of cases (e.g. Knudsen 1950) or will be inconclusive in poorly known systems and especially in species with planktonic larval development (e.g. Gustafson et al. 1991). In an extreme case, a parallel nomenclature was devised for egg capsules that could not be recognizably linked to benthic species (Tokioka 1950). Moreover, identification to species level can be complicated in some cases where spawn of several species are morphologically indistinguishable (e.g. simple gelatinous egg masses of some vetigastropods - Lebour 1937; Fretter \& Graham 1962; some species of Conus - Kohn 1961).

DNA barcodes are a promising and expedient new tool for accurately identifying and linking the varied life history stages of single species (Schindel \& Miller 2005). Indeed, DNA barcoding has demonstrated its capacity to do so successfully in several animal groups (Blaxter 2004; Steinke et al. 2005; Pegg et al. 2006; Thomas et al. 2005; Vences et al. 2005; Ahrens et al. 2007), and has already been used for marine fauna to link larvae and adults (Victor 2007). Such approaches have also been used to explore biodiversity, leading to the discovery of previously unrecognized species collected from their planktonic larvae while the difficult-to-collect adults are still unknown (Barber \& Boyce 2006). Among mollusks, and especially bivalves, molecular approaches have been used to identify larvae using rRNA 
probes for in situ hybridization (Le Goff-Vitry et al. 2007; Pradillon et al. 2007; Jones et al. 2008) or polymerase chain reaction-single strand conformation polymorphism (PCR-SSCP) combined with sequencing (Livi et al. 2006) of taxonomically informative fragments of $18 \mathrm{~S}$ rDNA. Such methods have been used primarily to confirm the identity of target species using species-specific probes developed from known adults and as such, have mostly practical utility in, e.g., biomonitoring of target, commercial or invasive species. Although it has been claimed that these methods may have broader utility for species identification by overcoming some of the limitations of mitochondrial markers (introgression, pseudogenes) (Livi et al. 2006), 18S rDNA faces the limitation that it is a highly conserved gene and will have decreased ability to accurately distinguish between closely related species. Recently, DNA barcodes in combination with other gene fragments (H3, 16S, 18S) were used to link egg masses, larvae and adults in one family of gastropods (Naticidae) in the western Mediterranean - a geographically circumscribed area with a well documented fauna (Huelsken et al. 2008).

Here, we assess the capacity of the animal barcode (COI), two additional mitochondrial markers (16S, 12S) and the existing genetic databanks (GenBank, Barcode of Life Database BOLD) to identify a set of unknown gastropod egg capsules collected in the megadiverse region of the Indo-Pacific as compared to identified gastropod egg cases from the welldocumented Mediterranean fauna. We use a two-tiered process first involving similaritybased methods (the identification engine of BOLD and the BLAST algorithm on GenBank), previously used in DNA barcode identification (e.g. Wong \& Hanner 2008), followed by phylogenetic reconstruction (using all available sequences in GenBank) to tentatively 
117 determine the sister taxa of unidentified egg capsules, when similarity-based methods are not 118 effective.

\section{Material and methods}

121 Sampling

122 Twenty-four egg capsules were collected in the Philippines on scattered hard substrates (e.g. 123 stones, shells) from soft bottoms by trawling, between 150 and 1450 meters, during the

124 Aurora 2007 deep sea cruise off the east coast of Luzon. All were tentatively recognized as 125 neogastropod capsules as most share the lenticular shape typical of many neogastropod egg 126 cases (Bandel 1976b) (Fig. 1C-H); one egg capsule was identified as that of a species of 127 Conus (Conidae, Neogastropoda - Fig. 1B) with the flask-like shape characteristic of the 128 genus. All capsules were first photographed on the substrate, then placed in 95\% ethanol. In 129 addition, two identified egg capsules (EC1, EC2) from the French Mediterranean coast were 130 used as a control, allowing us to assess the capacity of DNA barcodes to identify known 131 samples. Both were readily identifiable to species as Coralliophila meyendorffii broods egg 132 capsules in the mantle cavity, and adults of Erosaria spurca were found near the egg capsules 133 (Fig. 1A).

Sequencing

136 DNA was extracted from the whole egg capsule, using 6100 Nucleic Acid Prepstation system 137 (Applied Biosystem). Three gene fragments were amplified, corresponding to some of the 138 most represented molluscan genes in GenBank, and also to genes commonly used at the 139 species level (Hebert et al. 2003; Remigio \& Hebert 2003): (i) a 658 bp fragment of the 140 Cytochrome Oxidase I (COI) mitochondrial gene using universal primers LCO1490 and 
141 HCO2198 (Folmer et al. 1994), (ii) a 550 bp fragment of the $16 \mathrm{~S}$ mitochondrial gene using

142 primers $16 \mathrm{SH} \quad$ (CGTGATCTGAGTTCAGACCGG) and

143 (GTTTACCAAAAACATGGCTTC) and (iii) a 600 bp fragment of the 12S mitochondrial

144 gene using primers 12SI (TGCCAGCAGYCGCGGTTA) and 12SIII

145 (AGAGYGRCGGGCGATGTGT). All PCR reactions were performed in $25 \mu$ l, containing 3

146 ng of DNA, $1 \mathrm{X}$ reaction buffer, $2.5 \mathrm{mM} \mathrm{MgCl}_{2}, 0.26 \mathrm{mM} \mathrm{dNTP}, 0.3 \mu \mathrm{M}$ of each primer, $5 \%$

147 DMSO and 1.5 units of Q-Bio Taq, QBiogene for all genes. Thermocycles used for COI gene

148 are those described in Hebert et al. (2003); for 16S and 12S genes, they consisted in an initial

149 denaturation step at $94^{\circ} \mathrm{C}$ for $4^{\prime}$, followed by 30 cycles of denaturation at $94^{\circ} \mathrm{C}$ for $30^{\prime}$,

150 annealing at $52^{\circ} \mathrm{C}$ for $16 \mathrm{~S}$ and $54^{\circ} \mathrm{C}$ for $12 \mathrm{~S}$. The final extension was at $72^{\circ} \mathrm{C}$ for $10^{\prime}$. PCR

151 products were purified and sequenced by the Genoscope. In all cases, both directions were

152 sequenced to confirm accuracy of each haplotype (GenBank Accession Numbers: EU870520-

153 EU870589).

154

155 Species identification

156 A two-tiered approach was employed to identify egg capsules, the first step involving 157 similarity-based methods (identification engine of BOLD and BLAST search routine in 158 GenBank) and a second step involving tree-based methods using Bayesian analysis of

159 neogastropod sequences in GenBank. In the first step, each sequence was compared to 160 available GenBank sequences using the BLASTn search routine as implemented in GenBank 161 (default parameters). The best hit, as measured by percent maximum sequence identity, was 162 retained. In addition, each sequence was compared to all available barcode records in BOLD, 163 using the identification engine BOLD-IDS, with the option "searching all barcode records in BOLD”. This provides a list of similar sequences with the associated taxon name and the 
165 percent sequence similarity. Contrary to the BLAST algorithm, identification in BOLD is 166 based on genetic distances, and is not influenced by sequence length (Ratnasingham \& Hebert

In the second step, all egg capsule sequences were included in phylogenetic analyses to assess which sequences form molecular operational taxonomic units (OTUs) and to evaluate the higher taxonomic placement of the OTUs. All neogastropod COI, $16 \mathrm{~S}$ and $12 \mathrm{~S}$ sequences were initially included, but to limit the total number of sequences, only one sequence per species was retained. An alignment with egg capsule sequences was generated using ClustalW multiple alignment implemented in BioEdit version 7.0.5.3 (Hall 1999) and only those sequences corresponding to the fragments sequenced for the egg capsules were retained. Ultimately, 159, 127 and 54 (for COI, 16S and 12S, respectively) GenBank sequences were used for the phylogenetic analyses. Phylogenetic trees were constructed using Bayesian inference with MrBayes (Huelsenbeck et al. 2001) (two Markov chains, 2000000 generations each with a sampling frequency of one tree each hundred generations, four parallel analyses).

Similarity-based methods (BLAST, BOLD-IDS) followed by phylogeny reconstruction were implemented for each gene, except for BOLD-IDS identifications as BOLD only contains COI sequences. Match scores are provided for BOLD searches with COI, and for BLAST searches with all three genes. For each sample, a final identification, corresponding to the best similarity score for the three genes (match score superior to 95\%) and/or to the name of the sister taxa in the tree, is proposed based on the results of these analyses (see details in Table 1). 


\section{Results}

191 Similarity-based identifications

192 Of the 26 samples (24 unknown, 2 known), only one of the known Mediterranean samples

193 was identified to species using the BOLD identification engine (specimen EC2: 99.51\%

194 similarity with a sequence of Erosaria spurca), confirming the field-based identification 195 (Table 1). Of the Philippine samples, only specimen EC8 was tentatively identified to genus, 196 returning a match with a sequence of Comitas sp. (Turridae) at $97.84 \%$ similarity. All other 197 COI sequences returned matches at $84 \%$ to $89 \%$ similarity with one or several sequences in 198 BOLD, far exceeding the genetic distance considered to separate species (Hebert et al. 2003).

199 Similarly, only the specimen of Erosaria spurca was identified to species with COI alone using the BLAST search routine in GenBank (98\% identity); all other first hits returned matches at $76 \%$ to $90 \%$ sequence identity.

203 The two additional mitochondrial markers sequenced in this analysis (16S, 12S) did not fare 204 much better. Again, identification of specimen EC2 (Erosaria spurca) was confirmed with the $20516 \mathrm{~S}$ gene (99\% identity) and the 12S sequence of specimen EC1 returned a match with a 206 sequence of Coralliophila meyendorffii at 99\% identity, confirming the field-based 207 identification of the second Mediterranean sample. These were the only matches at species 208 level. However, twelve 16S egg capsule sequences produced matches with a 16S sequence of 209 Granulifusus niponicus at between 95\% and 98\% identity, and the 16S sequence of specimen 210 EC3 matched with a sequence of Conus radiatus at 95\% identity; these results tentatively 211 suggest a higher taxonomic identification at genus level (but see Discussion, below). All other 
matches for the $16 \mathrm{~S}$ gene ranged from $82 \%$ to $89 \%$ identity, while those for the $12 \mathrm{~S}$ gene ranged from only $79 \%$ to $94 \%$ identity.

\section{Tree-based identifications}

216 Among the 26 samples, 11 molecular OTUs were recognized using phylogeny reconstruction

(Table 1). As shown for the 16S gene (Fig. 2), the phylogenetic placement of these OTUs can be used to confirm similarity-based identifications, but also to suggest supra-specific identifications when identification to species level is not possible based on sequence similarity. For example, with the $16 \mathrm{~S}$ gene, the 12 sequences comprising OTU 4 form a clade 221 with the GenBank sequence of G. niponicus (posterior probability PP = 0.98) (Fig. 2). EC23 222 (OTU 10) and EC26 (OTU 11) form a clade with Raphitoma linearis (Conidae, 223 Raphitominae) with a PP of 1 . With the 12S gene (results not shown), OTU 8 (EC 12, 15) clusters in a group with EC8 composed exclusively of Turridae species (PP $=0.97)$. With the

225 COI gene (results not shown), OTU 5 (EC5, 6 and 7) is closely related to a sequence of 226 Belomitra sp. (Buccinidae) $(\mathrm{PP}=1)$. This identification was already suggested with the 227 BLAST search routine in GenBank, but only with 89\% identity. The COI gene tree also 228 identifies EC23 as a member of the Raphitominae (Conidae) and EC26 as a member of the 229 Clathurellinae (Conidae), thereby refining the 16S familial placement of these two egg 230 capsules.

\section{Discussion}

233 Eggs capsule identification

234 Identification of the egg capsules of Erosaria spurca collected in France illustrates the 235 capacity of the animal DNA barcode to successfully link the different life stages of a single 
gastropod species. However, only one of the two Mediterranean samples was identified by the COI barcode with a high level of precision (i.e. species level at $>98 \%$ similarity). None of the Philippine egg capsules were identified with the same level of precision using COI alone. The threshold routinely used to consider two COI sequences as belonging to the same OTU ranges

240 from 1\% to 2\% (Hebert et al. 2004; Bichain et al. 2007; Ratnasingham \& Hebert 2007), and 241 except for the specimen of Erosaria spurca, match scores for all other samples exceed this threshold. Similarly, only the Mediterranean samples retrieved matches at $>98 \%$ sequence similarity for the $16 \mathrm{~S}$ and $12 \mathrm{~S}$ markers; species identification was confirmed for specimen EC2 (Erosaria spurca) with 16S (99\% identity) and for specimen EC1 (Coralliophila meyendorffii) with 12S (also 99\% identity).

For many of the remaining samples, a supra-specific identification was possible based on match scores or using a combination of similarity- and tree-based methods. For example, although a genus-level genetic threshold is difficult to specify and will vary greatly between taxa (Holland et al. 2004), a low genetic distance ( $\leq 5 \%)$ tentatively supports a genus-level identification for OTU6 (97.84\% - Comitas sp.) based on COI and for OTU3 (95\% - Conus 252 radiatus) and OTU4 (95-98\% - Granulifusus niponicus) based on 16S (see Fig. 3). The 253 positioning of OTUs in the phylogenetic tree confirms these similarity-based identifications, 254 but can also refine them in some cases. For example, the COI sequence for EC23 returned 255 matches with Nannodiella (Conidae, Clathurellinae) in BOLD (87.4\%) and with Gymnobela 256 (Conidae, Raphitominae) in GenBank (86\%), suggesting a family-level identification 257 (Conidae). In the COI gene tree, EC23 is more closely related to Nannodiella, thereby 258 suggesting that EC23 is a Clathurellinae. 
260 Three egg capsules (OTU7, 9) could not be assigned even a tentative supra-specific 261 identification based on the combination of similarity- and tree-based methods (see Table 1).

262 Hit scores for these samples for all three genes are inferior to 90\%; BLAST and BOLD results 263 indicate that when the first matching sequence displays low sequence similarity (i.e. $<90 \%$ ), 264 the following matching sequences correspond (with lower or similar percentage) to 265 completely different taxa. For example, BLAST results indicate that the COI sequence of EC3 266 matches first with Lacuna pallidula (Littorinidae) with a sequence identity of 85\%, but then 267 with Nucella lamellosa (Neogastropoda, Muricidae) with the same score, with Ilyanassa 268 obsoleta (Neogastropoda, Nassaridae) at 84\% identity and with Urosalpinx perrugata 269 (Neogastropoda, Muricidae) also at 84\%. Consequently, such scores are not useful for 270 hypothesizing even superfamily-level identifications with a high degree of certainty. 271 Moreover, the relationships of these samples were not robustly resolved in the phylogenetic 272 analyses, preventing a family-level identification. However, this is not true in all cases. For 273 example, OTU5 returned matches with Belomitra sp. (Buccinidae) in GenBank at 89\% 274 sequence identity, and this identification is supported by the phylogenetic analyses. In the 275 case of specimens EC12 and EC15 (OTU8), BOLD and GenBank best hits for 12S correspond to turrid species with low sequence similarity (Gemmula rosario for EC12, 83\%, 277 and Lophiotoma unedo for EC15, 79\%), but the 12S gene tree tentatively supports this 278 identification at family rank (Turridae).

280 Morphology of eggs capsules

281 Specimen EC3 has a morphology typical of Conus species with its flask-like shape (Fig. 1 B), 282 and DNA analysis confirms this hypothesis. Specimen EC5, identified as Belomitra sp. 283 (Buccinidae) is globular (Fig. 1 E). Although Belomitra egg morphology has never been 
described, this result is consistent with the literature, as similar egg capsule shapes have been already reported for several buccinid genera (Thorson 1935, 1940a). All other egg capsules examined in the present study share a similar lenticular shape, with an escape aperture at the apex of the capsule, and containing a variable number of eggs. This morphology is not common among fasciolarids (see e.g. Knudsen 1950) which instead usually have flask or vase-shaped capsules, sometimes with an undulating apical ridge or keel that surrounds the escape aperture. Here, lenticular capsules were tentatively identified as Granulifusus sp. (Fig. $1 \mathrm{D})$ which would be the first record of an egg case for this genus.

Database completeness

Accuracy of DNA-based identification is dependent, of course, on the maturity of existing genetic databases. The impediment that incomplete databases pose for accurate and precise species identification has already been acknowledged, but how incomplete are they, and how does existing taxonomic coverage accurately mirror known diversity? The present analysis clearly indicates that even well-known faunas are inadequately represented in existing databases as evidenced by the fact only one of two samples from the French Mediterranean fauna could be identified to species using COI alone. It is surprising that even a well-known species as Coralliophila meyendorffii is not represented in databases for the COI and $16 \mathrm{~S}$ genes; indeed, there is not a single $16 \mathrm{~S}$ coralliophiline sequence and only one for the COI gene in these databases - a clade with roughly 250 species worldwide that form ecologically important associations with Cnidaria. Phylogenetic analysis can provide a supra-specific 305 identification in cases where similarity-based methods return matches with only low similarity, and is the best alternative when no sequences of the same species are present in the 
of caution. The weak phylogenetic signal of each gene alone does not allow a robust resolution of the phylogenetic relationships among neogastropods and most family-level relationships are not well supported. Concatenation of all three genes to improve resolution of

311 the tree is not possible due to high levels of terminal mismatch - yet another measure of the 312 incompleteness of existing databases.

314 Tallying the number of sequences available provides a more concrete measure of database 315 completeness, although we must assume that all specimens have been identified correctly. Despite this caveat, by this measure taxonomic diversity of mollusks is severely 317 underrepresented, as less than 16,000 molluscan COI sequences are currently published in 318 GenBank, ostensibly corresponding to 3,688 species, or less than $2 \%$ of the roughly 80,000 319 valid species (of which 53,000 are marine; Bouchet 2006) already described. But equally 320 important is the taxonomic distribution of available sequences. In order to quantify taxonomic 321 coverage, we compared gastropod species richness by family at a well-sampled tropical site in 322 New Caledonia (Koumac - Bouchet et al. 2002) with the number of COI sequences available 323 in GenBank over the last three years (Fig. 4). The results illustrate several important biases in 324 family representation in GenBank. For example, five of the six most speciose families at 325 Koumac (Triphoridae, Eulimidae, Pyramidellidae, Cerithiopsidae, Costellariidae) are each 326 represented by less than three COI sequences. These families are all highly diverse and 327 taxonomically complex with large numbers of minute species that classically have been 328 overlooked in systematic studies. To complicate matters, they are almost exclusively 329 predatory and typically occur in low abundance, with as many as $20 \%$ of the species known 330 only from single specimens at any given site (Bouchet et al. 2002). 
Conversely, some families are conspicuously over-represented, with the number of sequences available disproportionate to their known global diversity. Among the marine families, these over-represented groups tend to be large, charismatic "sea shells" of interest to collectors and hobby naturalists (Cypraeidae, Muricidae). For example, the Cypraeidae comprises 230 species worldwide (Lorenz 2002) and are represented by 682 COI sequences in GenBank. Whereas for Turridae s.l. (Conoideans except Terebridae and Conus), the most speciose assemblage at Koumac and with about 4,000 named valid species (Tucker 2004) and perhaps as many as 10-20,000 in reality (Kantor et al. in press), there are only 92 COI sequences available. The other well-represented marine families (e.g. Littorinidae, Neritidae) are 341 similarly disproportionately represented given their known diversity, and tend to be easily 342 accessible and abundant in shallow, near shore habitats.

344 A comparison of the number of sequences available in GenBank between 2006 and 2008 345 shows a slight increase in the number of sequences for most families, with several showing 346 more significant increases (e.g. Conus, Littorinidae, Neritidae, Turridae s.l.). The overall 347 number of sequences and sudden increases in sequence availability can often be traced to the 348 contributions of a single individual or research group. These may represent large numbers of 349 sequences for a limited number of species (e.g. population genetic studies of Neritidae) or 350 targeted systematic studies of particular taxonomic groups. For example, of the 92 COI turrid 351 s.l. sequences available, all but one (109/110) were generated by our own research group. The 352 potential impact of such targeted studies is evident when comparing the resolving power of 353 existing databases including and excluding our own sequences (see Fig. 3). However, the 354 majority of the most speciose families remain enormously underrepresented. 


\section{Conclusion}

357 The COI gene, the universal barcode for animals, in association with two other mitochondrial 358 markers, has demonstrated its ability to identify gastropod spawn, and thus constitutes an 359 important tool for taxonomic identification of various animal life stages. However, our results 360 indicate that sequence availability in existing genetic databases is disproportionately low 361 given the known and estimated diversity of gastropods, and that the taxonomic coverage is 362 highly biased towards shallow water species and/or highly collectible macro-mollusks. 363 Consequently, barcodes are currently unable to provide species-level identifications for most 364 unknowns, even for well-known, shallow water European species. In cases when species-level 365 identification is impossible, tree-based methods are useful for refining the higher taxonomic 366 placement of unidentified samples, but should be treated with caution. Barcoding efforts 367 under development for targeted vertebrates (birds, fishes), "charismatic" invertebrates or 368 economically important groups currently allow positive identification to species in 99\% of 369 unknowns in some cases (e.g. Wong \& Hanner 2008), but similar projects should be 370 developed for megadiverse groups such as mollusks, not only to facilitate taxonomic expertise 371 but also to enhance species discovery in such poorly known groups.

References

374 Ahrens D, Monaghan MT, Vogler AP (2007) DNA-based taxonomy for associating adults and larvae in multi-species assemblages of chafers (Coleoptera: Scarabaeidae). Molecular Phylogenetics and Evolution 44, 436-449.

377 Bandel K (1976a) Observations on spawn, embryonic development and ecology of some Caribbean lower Mesogastropoda. The Veliger 18, 249-270. 
Bandel K (1976b) Spawning, Development and ecology of some higher neogastropoda from the Carribean Sea of Colombia (South America). The Veliger 19, 176-193.

Barber P, Boyce SL (2006) Estimating diversity of Indo-Pacific coral reef stomatopods through DNA barcoding of stomatopod larvae. Proceedings of the Royal Society $B$ 273, 2053-2061.

Bichain JM, Boisselier MC, Bouchet P, Samadi S (2007) Delimiting species in the genus Bythinella (Mollusca: Caenogastropoda: Rissooidea): molecular and morphometric approachs. Malacologia 49, 291-311.

Blaxter ML (2004) The promise of a DNA taxonomy. Philosophical Transactions of the Royal Society of London B 359, 669-679.

Bouchet P (2006) The magnitude of marine biodiversity. In: The Exploration of Marine Biodiversity - Scientific and Technological Challenges (ed. BBVA F).

Bouchet P, Lozouet P, Maestrati P, Héros V (2002) Assessing the magnitude of species richness in tropical marine environments : exceptionnally high numbers of molluscs at a new Caledonian site. Biological Journal of the Linnean Society 75, 421-436.

D’Asaro CN (1970) Egg capsules of prosobranch mollusks from south Florida and the Bahamas, and notes on spawning in the laboratory. Bulletin of Marine Science 20, 414-440.

Folmer O, Black M, Hoeh W, Lutz R, Vrijenhoek R (1994) DNA primers for amplification of mitochondrial cytochrome c oxidase subunit I from diverse metazoan invertebrates. Molecular Marine Biology and Biotechnology 3, 294-299.

Fretter V, Graham A (1962) British Prosobranch Molluscs; their functional anatomy and ecology Ray Society, London. 
402

403

404

405

406

407

408

409

410

411

412

413

414

415

416

417

418

419

420

421

422

423

424

425

Gustafson RG, Littlewood DTJ, Lutz RA (1991) Gastropod egg capsules and their contents from deep-sea hydrothermal vent environments. Biological Bulletin 180, 34-55.

Habe T (1960) Egg masses and egg capsules of some Japanese marine prosobranchiate gastropod. Bulletin of the Marine Biological Station of Asamushi 10, 121-126.

Hall TA (1999) BioEdit: a user-friendly biological sequence alignment editor and analysis program for Windows 95/98/NT. Nucleic Acids Symposium Series 41, 95-98.

Hebert PDN, Cywinska A, Ball SL, deWaard JR (2003) Biological identifications through DNA Barcodes. Proceedings of the Royal Society B 270, 313-321.

Hebert PDN, Stoeckle MY, Zemlak TS, Francis CM (2004) Identification of birds through DNA barcodes. PLOS Biology 2, 1657-1663.

Holland BS, Dawson MN, Crow GL, Hofmann DK (2004) Global phylogeography of Cassiopea (Scyphozoa: Rhizostomeae): molecular evidence for cryptic species and multiple invasions of the Hawaiian Islands. Marine Biology 145, 1119-1128.

Huelsenbeck JP, Ronquist F, Hall B (2001) MrBayes: bayesian inference of phylogeny. Bioinformatics 17, 754-755.

Huelsken T, Marek T, Schreiber S, Schmidt I, Hollmann M (2008) The Naticidae (Mollusca: Gastropoda) of Giglio Island (Tuscany, Italy): Shell characters, live animals, and a molecular analysis of egg masses. Zootaxa 1770, 1-40.

Jones WJ, Preston CM, Marin R, Scholin CA, Vrijenhoek RC (2008) A robotic molecular method for in situ detection of marine invertebrate larvae. Molecular Ecology Resources 8, 540-550.

Kantor YI, Puillandre N, Olivera BM, Bouchet P (2008) Morphological proxies for taxonomic decisions in turrids (Mollusca, Neogastropoda): a test of the value of shell and radula characters using molecular data. Zoological Science, (in press). 
Knudsen J (1950) Egg capsules and development of some marine prosobranchs from tropical West Africa. Atlantide Report 1, 85-130.

Kohn AJ (1961) Studies on spawning behavior, egg masses, and larval development in the gastropod genus Conus, Part I. Observation on nine species in Hawaii. Pacific Science 15, 163-179.

Le Goff-Vitry MC, Chipman AD, Comtet T (2007) In situ hybridization on whole larvae: a novel method for monitoring bivalve larvae. Marine Ecology progress Series 343, 161-172.

Lebour MV (1937) The eggs and larvae of the British prosobranchs with special reference to those living in the plankton. Journal of the Marine Biological Association of the United Kingdom 22, 105-166.

Livi S, Cordisco C, Damiani C, Romanelli M, Crosetti D (2006) Identification of bivalve species at an early developmental stage through PCR-SSCP and sequence analysis of partial 18S rDNA. Marine Biology 149, 1149-1161.

Lorenz F (2002) New Worldwide cowries. Descriptions of new taxa and revisions of selected groups of living Cypraeidae (Mollusca: Gastropoda) Conchbooks.

Lutz R, Bouchet P, Jablonski D, Turner R, Warén A (1986) Larval ecology of mollusks at deep-sea hydrothermal vents. American Malacological Bulletin 4, 49-54.

Pegg GG, Sinclair B, Briskey L, Aspden WJ (2006) MtDNA barcode identification of fish larvae in the southern Great Barrier Reef, Australia. Scientia Marina 70, 7-12.

Pradillon F, Schmidt A, Peplies J, Dubilier N (2007) Species identification of marine invertebrate early stages by whole-larvae in situ hybridisation of $18 \mathrm{~S}$ ribosomal RNA. Marine Ecology progress Series 333, 103-116. 
Ratnasingham S, Hebert PDN (2007) BOLD : The Barcode of Life Data System. Molecular

450

451

452

453

454

455

456

457

458

459

460

461

462

463

464

465

466

467

468

469

470

471 Ecology Notes 7, 355-364.

Remigio EA, Hebert PDN (2003) Testing the utility of partial COI sequences for phylogenetic estimates of gastropod relationships. Molecular Phylogenetics and Evolution 29, 641647.

Robertson R (1974) Marine prosobranch gastropods: larval studies and systematics. Thalassia Jugoslavica 10, 213-238.

Schindel DE, Miller SE (2005) DNA barcoding a useful tool for taxonomists. Nature 435, 17.

Steinke D, Vences M, Salzburger W, Meyer A (2005) TaxI: a software tool for DNA barcoding using distance methods. Proceedings of the Royal Society B 360, 19751980.

Thomas M, Raharivololoniaina M, Glaw F, Vences M, Vireites DR (2005) Montane Tadpoles in Madagascar: Molecular Identification and Description of the Larval Stages of Mantidactylus elegans, Mantidactylus madecassus, and Boophis laurenti from the Andringitra Massif. Copeia 1, 174-183.

Thorson G (1935) Studies on the egg-capsules and development of Arctic marine prosobranchs. Medd. Om Gronland 100, 20-73.

Thorson G (1940a) Notes on the egg-capsules of some North-Atlantic prosobranchs of the genus Troschelia, Chysodomus, Volutopsis, Sipho and Trophon. Videnskabelige Meddelelser fra Dansk naturhistorisk Forening i Kobenhavn 104, 251-265.

Thorson G (1940b) Studies on the egg masses and larval development of Gastropoda from the Iranian Gulf. Danish Scientific Investigations in Iran, Part 2 Ejnar Munksgaard, Copenhagen. 
Tokioka R (1950) Droplets from the plankton net. V. New names for egg capsules of littorinid gastropods. Publication of the Seto Marine Biological Laboratory 1, 151-152.

Tucker JK (2004) Catalog of Recent and fossil turrids (Mollusca: Gastropoda). Zootaxa 682, $1-1295$.

Vences M, Thomas M, Bonett RM, Vieites DR (2005) Deciphering amphibian diversity through DNA barcoding: chances and challenges. Philosophical Transactions of the Royal Society B: Biological Sciences 360, 1859-1868.

Victor BC (2007) Coryphopterus kuna, a new goby (Perciformes: Gobiidae: Gobiinae) from the western Caribbean, with the identification of the late larval stage and an estimate of the pelagic larval duration. Zootaxa 1526, 51-61.

Winner BE (1987) A field guide to molluscan spawn. Vol. 1. EBM, North Palm Beach, Florida.

Wong EH-K, Hanner RH (2008) DNA barcoding detects market substitution in North American seafood. Food Research International 41, 828-837.

\section{Acknowledgments}

The AURORA 2007 cruise (Principal Investigators: Marivene Manuel, NMP, and Philippe Bouchet, MNHN) on board M/V DA-BFAR was a joint project between the Philippine Bureau of Fisheries and Aquatic Resources (BFAR), National Museum of the Philippines (NMP), and Muséum National d'Histoire Naturelle (MNHN). It was made possible by a grant from the Lounsbery Foundation, and was carried under a Census of Marine Life / Census of Margins umbrella. This work was supported by the "Consortium National de Recheche en Génomique", and the "Service de Systématique Moléculaire" of the Muséum National 
496 d'Histoire Naturelle (IFR 101). It is part of the agreement $n^{\circ} 2005 / 67$ between the Genoscope 497 and the Muséum National d'Histoire Naturelle on the project "Macrophylogeny of life" 498 directed by Guillaume Lecointre". We are grateful to André Hoareau and Jacques Pelorce for 499 the two specimens collected in France. We are also pleased to thank Barbara Buge (MNHN) 500 for the pictures of the egg capsules and Yuri Kantor (Russian Academy of Sciences) for 501 discussions about egg capsule morphology.

502 
504 Fig. 1: Egg capsules used in molecular analyses and resulting identifications. A. EC2 505 (Erosaria spurca - egg capsule with adults) B. EC3 (Conus sp.) C. EC9 (left) and EC11 506 (Granulifusus sp., at two different stages) D. EC8 (Comitas sp.) E. EC5 (Belomitra sp.) F. 507 EC14 (unidentified caenogastropod) G. EC23 (Conidae, Clathurellinae) H. EC26 (Conidae, 508 Raphitominae) fixed on a bivalve shell. Photo credits: André Hoareau (A) and Barbara Buge 509 (MNHN) (B-H). Color photos are also published in MorphoBank 510 (http://morphobank.geongrid.org/permalink/?P232)

512 Fig. 2: Bayesian phylogram generated from all 16S neogastropod sequences in GenBank and 51323 neogastropod egg capsule specimens from the Philippines and France. Erosaria spurca 514 (EC2), a non-neogastropod, is the outgroup.

Fig. 3: Number of positive identifications of unknown Philippine egg capsules at different taxonomic levels based on all genes (A, B) or COI only (C, D). A and C include all GenBank

518 sequences; B and D exclude sequences produced by our own research group, demonstrating the impact of a single research group on the global dataset.

521 Fig. 4: GenBank coverage and actual marine gastropod diversity for gastropod families.

522 Histogram on the left indicates number of COI sequences in GenBank: light gray - July 28,

523 2006; dark gray - April 6, 2007; black - July 4, 2008. Histogram on the right shows species

524 richness of gastropod families at a well-sampled tropical site (Koumac, New Caledonia;

525 Bouchet et al. 2002). Only groups with more than 10 species in Koumac or more than 100

526 sequences in GenBank (in 2006) are represented here. The decreasing of the number of 
527 sequences for some groups through time is due to the fact that some sequences were removed 528 from GenBank. 


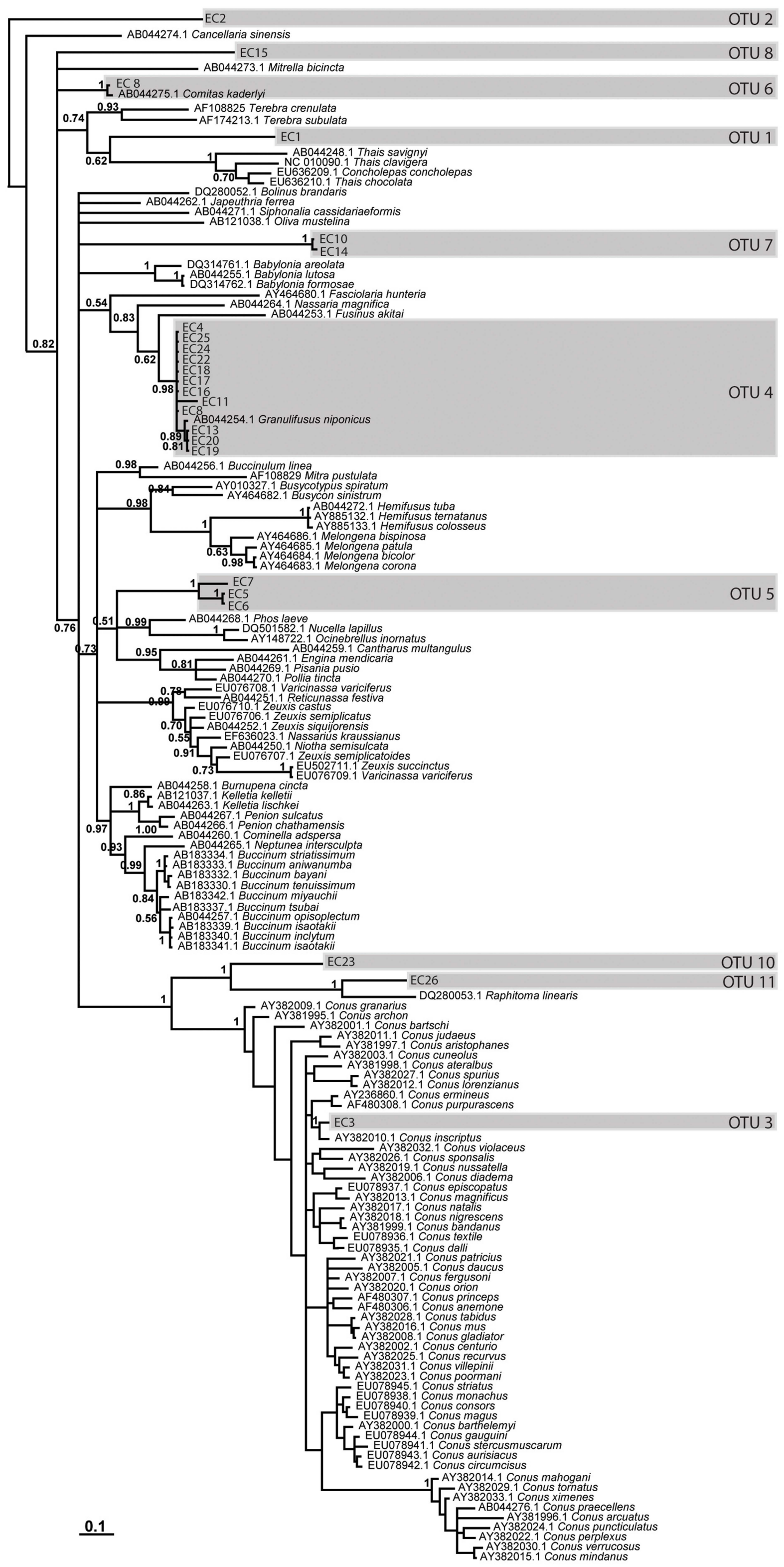


\begin{tabular}{l|l|l} 
No. of egg cases & OTUs & Family ID? \\
\hline
\end{tabular}

Species ID?

A

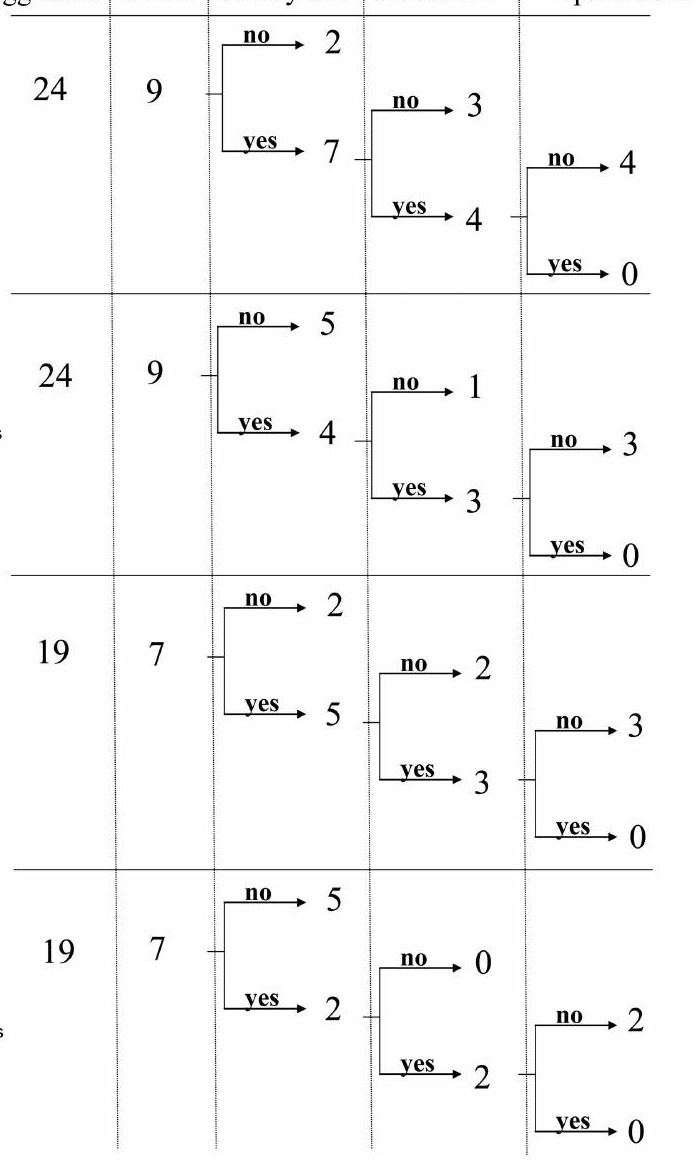

B

(MNHN

sequences excluded)

C

(COI only)

(COI only, MNHN sequences excluded)

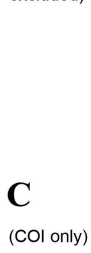

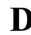 \\ D}




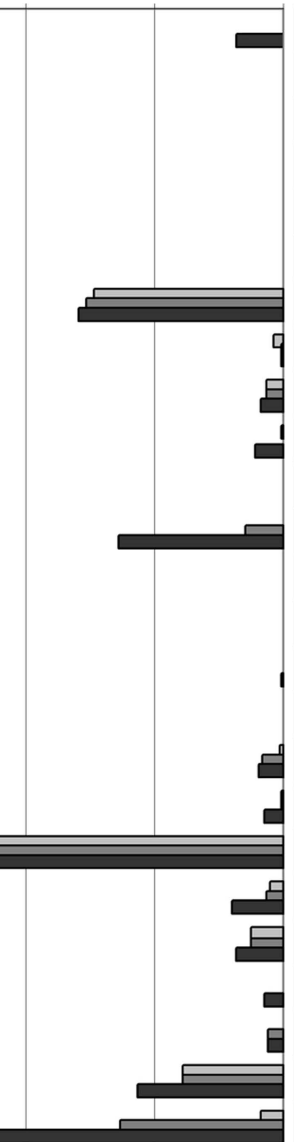

Turridae s.1.

Triphoridae

Eulimidae

Pyramidellidae

Cerithiopsidae

Costellariidae

Muricidae

Rissoidae

Trochidae

Bullomorpha

Mitridae

Conidae (Conus)

Epitoniidae

Columbellidae

Cerithiidae

Terebridae

Fissurellidae

Chromodorididae

Cypraeidae

Nassariidae

Buccinidae

Naticidae

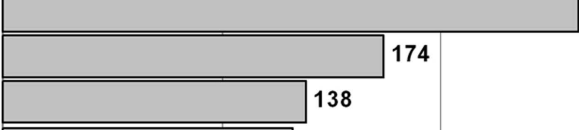

132

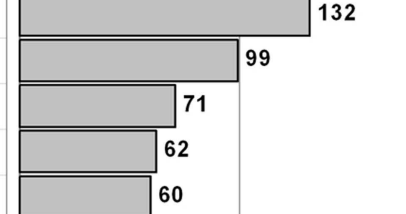




\begin{tabular}{|c|c|c|c|c|c|c|c|c|c|}
\hline & & & & & & & \multirow{2}{*}{\multicolumn{3}{|c|}{ COI }} \\
\hline & & & & & & & & & \\
\hline & & & & & & & \multicolumn{2}{|l|}{ BOLD } & Genbank \\
\hline ID & \begin{tabular}{|l|} 
Station \\
\end{tabular} & COI & $16 S$ & 12S & $\mathbf{N}^{\circ}$ & OTU & ID & $\%$ & ID \\
\hline P3 & & EU870569 & EU870545 & EU870520 & EC1 & 1 & $\mathrm{x}$ & $\mathrm{x}$ & Fluminicola virens \\
\hline $\mathrm{P} 4$ & & EU870570 & EU870546 & EU870521 & EC2 & 2 & Erosaria spurca & \begin{tabular}{|l|}
99,51 \\
\end{tabular} & Erosaria spurca \\
\hline 496 & \begin{tabular}{|l|} 
CP2665 \\
\end{tabular} & EU870571 & EU870547 & EU870522 & EC3 & 3 & Conus sulcatus & \begin{tabular}{|l|}
88,94 \\
\end{tabular} & Conus venulatus \\
\hline 648 & \begin{tabular}{|l|}
$\mathrm{CP} 2678$ \\
\end{tabular} & EU870572 & EU870548 & EU870523 & EC4 & 4 & Busycon carica & \begin{tabular}{|l|}
87,19 \\
\end{tabular} & Busycon sinistrum \\
\hline 694 & CP2684 & EU870573 & EU870549 & EU870524 & EC5 & 5 & Batillaria multiformis & 87,63 & Belomitra sp. \\
\hline 695 & CP2684 & EU870574 & EU870550 & EU870525 & EC6 & 5 & Batillaria multiformis & 87,45 & Belomitra sp. \\
\hline 696 & \begin{tabular}{|l|}
$\mathrm{CP} 2684$ \\
\end{tabular} & EU870575 & EU870551 & EU870526 & EC7 & 5 & Busycon sinistrum & 85,74 & Belomitra sp. \\
\hline 861 & CC2700 & EU870576 & EU870552 & EU870527 & EC8 & 6 & Comitas & 97,84 & Pyrgulopsis glandulosa \\
\hline 898 & \begin{tabular}{|l|}
$\mathrm{CP} 2707$ \\
\end{tabular} & EU870577 & EU870553 & EU870528 & \begin{tabular}{|l|} 
EC9 \\
\end{tabular} & 4 & Busycon carica & 87,26 & Nucella lapillus \\
\hline 1057 & CP2712 & EU870578 & EU870554 & EU870529 & EC10 & 7 & Lacuna pallidula & 84,64 & Ilyanessa obsoleta \\
\hline 1285 & CC2724 & & EU870555 & EU870530 & \begin{tabular}{|l|} 
EC11 \\
\end{tabular} & 4 & & & \\
\hline 1402 & \begin{tabular}{|l|} 
CP2727 \\
\end{tabular} & & & EU870531 & EC12 & 8 & & & \\
\hline 1404 & \begin{tabular}{|l|}
$\mathrm{CP} 2727$ \\
\end{tabular} & EU870579 & EU870556 & EU870532 & \begin{tabular}{|l|} 
EC13 \\
\end{tabular} & 4 & Busycon carica & 87,61 & Ilyanessa \\
\hline 1405 & \begin{tabular}{|l|} 
CP2727 \\
\end{tabular} & & EU870557 & & \begin{tabular}{|l|} 
EC14 \\
\end{tabular} & 7 & & & \\
\hline 1409 & \begin{tabular}{|l|} 
CP2727 \\
\end{tabular} & & EU870558 & EU870533 & EC15 & 8 & & & \\
\hline 1646 & \begin{tabular}{|l|}
$\mathrm{CP} 2735$ \\
\end{tabular} & EU870580 & EU870559 & EU870534 & \begin{tabular}{|l|} 
EC16 \\
\end{tabular} & 4 & Busycon carica & \begin{tabular}{|l|}
87,09 \\
\end{tabular} & Busycon sinistrum \\
\hline 1647 & CP2735 & EU870581 & EU870560 & EU870535 & EC17 & 4 & Busycon carica & 87,3 & Busycon sinistrum \\
\hline 1648 & CP2735 & EU870582 & EU870561 & EU870536 & \begin{tabular}{|l|} 
EC18 \\
\end{tabular} & 4 & Busycon carica & 86,99 & Busycon sinistrum \\
\hline 1681 & \begin{tabular}{|l|} 
CC2743 \\
\end{tabular} & EU870583 & EU870562 & EU870537 & EC19 & 4 & Busycon carica & 87,26 & Acanthinucella punctulata \\
\hline 1682 & \begin{tabular}{|l|} 
CC2743 \\
\end{tabular} & EU870584 & EU870563 & EU870538 & EC20 & 4 & Busycon carica & 87,26 & Acanthinucella punctulata \\
\hline 1689 & CC2745 & & & EU870539 & \begin{tabular}{|l|} 
EC21 \\
\end{tabular} & 9 & & & \\
\hline 1690 & \begin{tabular}{|l|} 
CC2745 \\
\end{tabular} & EU870585 & EU870564 & EU870540 & EC22 & 4 & Busycon carica & \begin{tabular}{|l|}
87,37 \\
\end{tabular} & Busycon sinistrum \\
\hline 1691 & \begin{tabular}{|l|} 
CC2745 \\
\end{tabular} & EU870586 & EU870565 & EU870541 & EC23 & 10 & Nannodiella & 87,4 & Gymnobela sp. \\
\hline 1692 & CC2745 & EU870587 & EU870566 & EU870542 & EC24 & 4 & Busycon carica & 87,19 & Busycon sinistrum \\
\hline 1693 & CC2745 & EU870588 & EU870567 & EU870543 & EC25 & 4 & Busycon carica & 87,19 & Busycon sinistrum \\
\hline 1775 & \begin{tabular}{|l|} 
CP2751 \\
\end{tabular} & EU870589 & EU870568 & EU870544 & \begin{tabular}{|l|} 
EC26 \\
\end{tabular} & 11 & Gymnobela & \begin{tabular}{|l|}
87,52 \\
\end{tabular} & Nannodiella \\
\hline
\end{tabular}




\begin{tabular}{|c|c|c|c|c|c|c|c|}
\hline \multirow[b]{3}{*}{$\%$} & \multirow{3}{*}{ Tree } & \multicolumn{3}{|l|}{$16 S$} & \multicolumn{3}{|l|}{$12 S$} \\
\hline & & \multicolumn{2}{|l|}{ Genbank } & \multirow{2}{*}{ Tree } & \multicolumn{2}{|l|}{ Genbank } & \multirow{2}{*}{ Tree } \\
\hline & & ID & $\%$ & & ID & $\%$ & \\
\hline 76 & & Conus circumcisus & 82 & & Coralliophila meyendorffii & 99 & C. meyendorffii \\
\hline 98 & & Erosaria spurca & 99 & & Cypraea annulus & 94 & \\
\hline 90 & Conus sp. & Conus radiatus & 95 & Conus sp. & Conus textile & 90 & Conus \\
\hline 86 & & Granulifusus niponicus & 98 & G. niponicus & Ilyanassa obsoleta & 86 & \\
\hline 89 & Belomitra sp. & Buccinum opisoplectum & 89 & & Ilyanassa obsoleta & 84 & \\
\hline 89 & Belomitra sp. & Buccinum opisoplectum & 89 & & Ilyanassa obsoleta & 83 & \\
\hline 89 & Belomitra sp. & Burnupena cincta & 89 & & Gemmula sogodensis & 83 & \\
\hline 85 & Lophiotoma & Comitas kaderlyi & 98 & C. kaderlyi & Gemmula rosario & 84 & \\
\hline 87 & & Granulifusus niponicus & 98 & G. niponicus & Ilyanassa obsoleta & 87 & \\
\hline \multirow[t]{3}{*}{84} & & Buccinulum linea & 86 & & Ilyanassa obsoleta & 79 & \\
\hline & & Granulifusus niponicus & 95 & G. niponicus & Ilyanassa obsoleta & 87 & \\
\hline & & & & & Gemmula rosario & 83 & Turridae \\
\hline \multirow[t]{3}{*}{86} & & Granulifusus niponicus & 98 & G. niponicus & Ilyanassa obsoleta & 85 & \\
\hline & & Buccinulum linea & 85 & & & & \\
\hline & & Penion chathamensis & 85 & & Lophiotoma unedo & 79 & Turridae \\
\hline 86 & & Granulifusus niponicus & 97 & G. niponicus & Ilyanassa obsoleta & 86 & \\
\hline 86 & & Granulifusus niponicus & 98 & G. niponicus & Ilyanassa obsoleta & 86 & \\
\hline 85 & & Granulifusus niponicus & 98 & G. niponicus & Ilyanassa obsoleta & 86 & \\
\hline 84 & & Granulifusus niponicus & 98 & G. niponicus & Ilyanassa obsoleta & 86 & \\
\hline \multirow[t]{2}{*}{84} & & Granulifusus niponicus & 98 & G. niponicus & Ilyanassa obsoleta & 86 & \\
\hline & & & & & Lophiotoma polytropa & 84 & Cypraeidae \\
\hline 86 & & Granulifusus niponicus & 97 & G. niponicus & Ilyanassa obsoleta & 86 & \\
\hline 86 & Raphitominae & Conus consors & 86 & Conidae & Ilyanassa obsoleta & 82 & \\
\hline 86 & & Granulifusus niponicus & 97 & G. niponicus & Ilyanassa obsoleta & 87 & \\
\hline 86 & & Granulifusus niponicus & 97 & G. niponicus & Ilyanassa obsoleta & 87 & \\
\hline 87 & Clathurellinae & Raphitoma linearis & 87 & Conidae & Lophiotoma acuta & 81 & \\
\hline
\end{tabular}




\begin{tabular}{|c|}
\hline Final ID \\
\hline C. meyendorffii \\
\hline Erosaria spurca \\
\hline Conus sp. \\
\hline Granulifus sp. \\
\hline Belomitra sp. \\
\hline Belomitra sp. \\
\hline Belomitra sp. \\
\hline Comitas sp. \\
\hline Granulifus sp. \\
\hline ? \\
\hline Granulifus sp. \\
\hline Turridae \\
\hline Granulifus sp. \\
\hline ? \\
\hline Turridae \\
\hline Granulifus sp. \\
\hline Granulifus sp. \\
\hline Granulifus sp. \\
\hline Granulifus sp. \\
\hline Granulifus sp. \\
\hline ? \\
\hline Granulifus sp. \\
\hline Conidae (Raphitominae) \\
\hline Granulifus sp. \\
\hline Granulifus sp. \\
\hline Conidae (Clathurellinae) \\
\hline
\end{tabular}

